\title{
Political economy of youth smoking regulation
}

\author{
Harold A. Pollack \& Peter D. Jacobson \\ Department of Health Management and Policy, University of Michigan School of Public Health, Ann Arbor, MI, USA
}

Correspondence to:

Harold Pollack

University of Michigan School of

Public Health

109 Observatory

Ann Arbor

MI 48109-2029

USA

E-mail: haroldp@umich.edu

\begin{abstract}
This paper considers the political economy of tobacco regulation-that is, the interplay between politics and markets in tobacco regulation. In surveying the interest-group politics of tobacco control, it describes political advantages held by a profitable and concentrated industry engaged in tobacco production. It also considers reasons for the surprising political success of tobacco control advocates over the past decade. The paper considers challenges faced by tobacco control advocates, who face their own obstacles to collective action in promoting effective tobacco regulation. Both public officials and tobacco control advocates face stronger incentives to advocate new legislation than they do to ensure effective implementation of existing regulatory measures. The essay concludes by considering the Master Settlement Agreement, whose detailed implementation remains uncertain after the election of the Bush administration.
\end{abstract}

KEYWORDS Adolescent, master settlement agreement, political economy, smoking.

\section{INTRODUCTION}

Youth smoking is influenced by a social context that helps shape both available supply and the current demand for tobacco products. Other papers in this issue consider specific factors: the role of family, tobacco prices, age-specific tobacco regulations, media presentation of pro-smoking and antismoking messages, school-based, communitybased and clinically based prevention efforts. Our companion authors document that much is known about the causal pathways leading to youth smoking. Much is also known about the effectiveness of prevention interventions to prevent, to limit, or to halt tobacco use among adolescents and young adults [1].

If public policy were the straightforward application of clinical research and program evaluation, the research summarized in this issue would provide a powerful roadmap for well-targeted, effective and cost-effective measures that alter the social, economic and regulatory environment that encourages youth smoking. In fact, however, the policy environment is shaped by powerful actors who respond to political and economic incentives in the tobacco policy debate.

Because economic, organizational, and political incentives are central to youth tobacco control, political economy is critical to the formation, implementation and continuation of public health policy. That is, one must consider the interplay of markets, electoral politics and government policy in shaping legislative action, in shaping the response of private action to public policy, and in shaping policy implementation in specific settings [2].

\section{ROADMAP OF THIS PAPER}

This paper considers the political economy of tobacco control in historical context. We begin by defining our own use of the term to connote the interest-group politics of tobacco regulation. We then consider the historical background to current regulatory efforts, along with the diverse cast of constituencies that influence tobacco regulation. As described below, the most puzzling aspect of this story is not the continued strength of the tobacco industry, but the industry's remarkable change in political fortunes in recent years. We then discuss the most prominent policy interventions designed to reduce tobacco-related health harms. Finally, we offer lessons for public policy in the wake of the Master Settlement Agreement. 


\section{THE DOMAIN OF POLITICAL ECONOMY}

The term 'political economy' has many different meanings and has spawned many disciplines and literatures. The economist who scrutinizes information gains in public regulation considers herself a scholar of political economy, although her work has little in common with the Marxian sociologist who uses social theory to examine the roots of labor-replacing technological change [3].

Our own use of the term is more empirical and less theoretically grounded than either of these disparate approaches. Informed by recent analyses of electoral politics and public regulation, $[2,4,5]$ we focus on the interest-group politics of tobacco control. We examine the interplay between mobilized and potential constituencies, and consider how these constituencies seek to influence regulators and elected legislators. We draw upon the existing empirical literature to examine the history of tobacco control. By comparing the disparate histories of different tobacco control efforts, we hope to illuminate ways that political context can influence regulatory outcomes.

In performing such an analysis, we are mindful that individual motives and circumstances are too diverse to be captured by any one analytic model. Moreover, an account overly focused on material incentives easily overlooks the independent force of moral, political and ideological concerns in influencing the behavior of important actors [6]. Such qualifications especially apply when one considers a critical arena to life and health such as tobacco control.

Even acknowledging these limitations, there are also predictable patterns in the actions of elected politicians, public regulators, antitobacco activists and private firms that reflect both powerful incentives and powerful constraints imposed by the unique circumstances of tobacco regulation. Understanding this unique political and economic environment is therefore critical to the design of feasible and politically sustainable tobacco control efforts.

Few readers need to be told that this environment is shaped by a myriad of interacting social, political, economic and historical factors. We cannot provide a full and adequate account of each of these factors. One must choose based upon one's expertise, and based upon what one hopes to accomplish. We choose this approach based upon our own previous research, and based upon what we hope to accomplish in a short paper addressed to the public health community. We acknowledge that we therefore avoid critical social questions - questions that might, quite properly, be considered within the domain of political economy. Our analysis also focuses on the United States. International tobacco control-particularly in the context of developing nations-raises policy issues beyond the scope of this paper [7].
As Mark Nichter and the editor remind us, one significant omission concerns the nature and the malleability of consumer preferences. Although we cannot address this subject adequately in the current essay, we would be remiss not to acknowledge these concerns.

Both Jon Elster and Amartya Sen have emphasized that the malleability of preferences strikes at the heart of welfare economics, challenging the uncritical acceptance of market outcomes as a means to efficiently promote individual well-being [8,9]. The argument that preferences are malleable can be applied in a paternalistic and undemocratic way, used to over-ride men and women's actual preferences in favor of one's own. Yet when one can identify specific strategies of deception or manipulation that seek to alter consumer preferences, arguments for public interventions that counter-act such manipulation become more compelling [10].

In particular, the demand for tobacco products arises and is reinforced in a particular context - a context in which tobacco producers and others stimulate consumer preferences for an addictive substance known to cause severe harm. Although one might consider competitive markets to arise in response to prior expressed consumer desires, these desires are themselves suggested, encouraged and reinforced by market actors. Tobacco marketing therefore provides an extreme antidote to bromides that depict the competitive marketplace as a charitable enterprise. Firms deploy the range of available marketing tools to perpetuate tobacco use. As described elsewhere in this issue, these tools include advertising designed to shape the preferences of adolescents and young consumers.

In some cases, firms appeal to young consumers through the use of 'comic strip' advertising and other modalities designed to reach 'young smokers'. In other cases, firms seek to identify tobacco use with circumstances and personal traits that are especially prized by young people: autonomy, attractiveness, nonconformity, willingness to take risk $[11,12]$.

Less directly, but perhaps of equal significance, the relationship between tobacco use, income and education is also pertinent to the political economy of tobacco use. Smoking is strongly and negatively correlated with socio-economic status [13]. The prevalence of tobacco use sharply declines with income and education - to the point that some public health advocates have become uncomfortable about the increasing regressivity of tobacco excise taxes [14,15]. Education gradients in overall smoking and in specific smoking-related risks are even more dramatic. For example, a recent analysis of smoking by women indicated that high school dropouts were nine times more likely to smoke during pregnancy as were pregnant college graduates [16]. 
One reason for these gradients is that smoking is closely linked with other social and health risks that arise, and are often reinforced, under conditions of socioeconomic disadvantage $[13,17]$. Tobacco use, a nominally individual behavior, is influenced by broader political and economic factors to influence human health. Although one might view continued tobacco use as an individual decision made in consideration of known risks [18], many features of tobacco epidemiology suggest that smoking is strongly influenced by social, political, and economic factors.

For example, nicotine is used widely to reduce stress. Ironically, smoking is prevalent among health-care workers and new mothers to address the tedium and stress associated with caregiving roles (see References in [19]). Smoking is also correlated with psychiatric disorders such as depression and with other substance use [20]. Presumably because smoking is a marker for unobserved individual characteristics and circumstances, smoking is also associated with increased likelihood of welfare receipt among low-income single mothers [21].

Although the remainder of our essay explores rather narrowly the interest-group politics of American tobacco control, we recognize that a different analysis could richly examine a very different set of social concerns.

\section{HISTORICAL BACKGROUND}

Before considering pertinent economic interests and political constituencies, it is useful to rehearse the dizzying change in tobacco control politics over the past decade.

In 1990, tobacco was a well-recognized killer, but remained arguably the least-regulated consumer product in America [11]. In some frustration, economist Thomas Schelling noted that more people die from smoking every year than are employed by the entire tobacco industry [22]. Smoking was deemed responsible for more than 300000 adult deaths [23]. Environmental tobacco smoke was a long-known contributor to many pediatric ailments, including childhood asthma. [23,24]. In-utero tobacco exposures were long the most prevalent source of prenatal substance use, and were important causes of many adverse infant health outcomes, including approximately 30000 low birth weight deliveries and 1000 cases of sudden infant death syndrome annually $[16,19,25,26]$.

Fires ignited by cigarettes or by cigarette lighters are associated with $29 \%$ of US fire deaths, causing approximately 1000 deaths and 3000 serious injuries annually [27-29]. Yet despite publicized litigation and product recalls arising from automobile safety defects, the more prevalent problem of tobacco-related fires attracted little systematic attention from the industry, from regulators, or from the general public.

Despite these known health hazards, cigarette manufacturers, upstream suppliers and downstream retailers have thwarted many efforts to reduce tobacco use. Defined for regulatory purposes to be neither food, nor medication, nor medical device, cigarettes were immune from basic FDA or product-safety regulation. In a time of billion-dollar class-action suits against the makers of breast implants and contraceptive devices, the tobacco industry avoided paying a dime in actual or punitive damages.

In the political realm, tobacco farmers and the tobacco industry enjoyed strong relationships with both political parties. President Carter vacationed at the farm of Smith Bagley, heir to the R.J.R. Reynolds fortune, and employed a tobacco lobbyist as his liason with the business community during his 1976 election campaign [30]. The tobacco industry enjoyed cordial relations with the Reagan and Bush administrations, although the industry did tangle with Surgeon General C. Everett Koop, Louis Sullivan and with other health officials [31]. During the early Clinton years, important figures such as Richard Gephardt, not generally associated with the tobacco debate, continued to receive substantial contributions from tobacco sources [32].

Outside government, the tobacco industry enjoyed cordial relations with conservative political lobbying groups, and with libertarian-minded advocacy groups that oppose specific measures for tobacco control. Tobacco producers were welcome participants and funders in many charitable activities across the country [33]. Tobacco firms confidentially donated more than $\$ 1$ million to the American Civil Liberties Union, which supported the tobacco industry on many regulatory matters [34]. According to an expose published by former Washington Post reporter Morton Mintz, tobacco industry funds were earmarked for a national ACLU task force advocating smokers' rights legislation. Mintz reports that the ACLU also opposed curbs on tobacco advertising and new cigarette warning labels [35].

Although tobacco advertisements were banned from television, tobacco was advertised aggressively in most other communication media. In 1991, tobacco firms spent nearly $\$ 280$ million on magazine advertisements, down from a peak of $\$ 426$ million in 1984 [36]. That same year, tobacco firms spent $\$ 386$ million on outdoor advertising, $\$ 60$ million on transit advertisements and $\$ 344$ million on point-of-sale promotional materials.

Sporting events such as Winston Cup racing epitomized tobacco's presence at the highest levels of professional sports [37]. In 1991, FTC documents indicate that tobacco companies spent $\$ 109$ million on promotions at sporting events [36]. Subsidies to Virginia Slims tennis 
and to community organizations epitomized the industry's successful efforts to reach women and minority consumers, even as the industry sought to maintain political legitimacy with important social groups [33]. Outside the area of cigarettes, use of spit tobacco by young men has also been linked with consumption by elite athletes [38].

As documented elsewhere in this volume, youthoriented advertising such as Joe Camel proved attractive to adolescents [39] and have been associated with increased adolescent smoking initiation. More subtly, but well-identified in subsequent research, heavy advertising by tobacco firms deterred aggressive news coverage of tobacco health issues by both print and electronic media [40,41].

On Wall Street, tobacco producers were favored targets for corporate takeovers and leveraged buy-outs. Bryan Burrough's 1990 best-seller Barbarians at the Gate epitomized investor interest in profiting from the strong underlying business fundamentals of tobacco sales [42].

Within less than a decade, the economics and politics of tobacco control radically changed. Under the nationwide Master Settlement Agreement, tobacco producers will eventually pay more than $\$ 200$ billion (less in present-value terms) to state governments to settle outstanding liabilities for smoking-related health care costs. With the exact provisions continuing to be negotiated, the settlement includes significant restrictions on tobacco advertising and specific provisions designed to prevent youth smoking [43].

In the political realm, tobacco company executives were humiliated in an unusual Congressional hearing in which CEOs were questioned sharply about their honesty and about the addictive properties of nicotine. Vice President Gore, once a strong tobacco supporter, rebuked the industry in a 1992 Democratic Convention speech describing his sister's death from lung cancer [11].

Despite strong advocacy by Senators and Representatives from tobacco-producing states, and despite large tobacco-related campaign contributions to both major parties, many elected politicians criticize the industry harshly for its advertising practices and for the impact of smoking on public health [44]. Richard Gephardt and other former supporters distanced themselves from the industry as tobacco control became a polarized issue in the 1996 and 2000 Presidential campaigns [32].

Within the regulatory realm, the 1990s brought a series of excise taxes increases, and a series of comprehensive and youth-specific antismoking regulations. New York, California, Massachusetts and other states enacted large tobacco excise tax increases $[45,46]$. Under the Balanced Budget Act of 1997 the federal government also increased tobacco excise taxes by $\$ 0.15$ per pack [43].

Measures to restrict adolescent consumption became a major focus of policy attention. The effectiveness of such measures has been disputed [47-49]. Moreover, some antitobacco activists criticize the framing of youth access as the critical policy concern [50]. Whatever the outcome of this debate, youth prevention became a popular goal in both the public rhetoric of tobacco control and in the design of specific legislation at all levels of American government.

By the first quarter of 2000, 40 states imposed restrictions on cigarette vending machines to restrict youth access [45]. Diverse antitobacco public information campaigns were implemented in many states and localities. The impact and cost-effectiveness of these interventions is the subject of current research [49].

In many states, the right of non-smokers to a smokefree work or entertainment space also became a legal entitlement rather than a matter of social convention. Thirty states established some clean air restrictions in restaurants. Twenty states established some form of smokefree indoor air restrictions in private work-sites, and 42 established similar regulations within state government facilities [45].

On Wall Street, tobacco stocks declined in parallel with expanding tobacco control efforts. Between September 1995 and September 2000, the Dow Jones Industrial Average more than doubled, but the Dow Jones tobacco index declined by $7.75 \%$ [51]. Some industry analysts speculate openly that recent litigation might bankrupt the industry, although tobacco stock prices increased during the last quarter of 2000 [51].

The changing fortunes of the tobacco industry raise three related puzzles:

- Why did the political economy of tobacco regulation change so quickly?

- Why has the industry proved so difficult to regulate despite clear and widely accepted scientific evidence of health harms associated with tobacco use?

- Perhaps most important, how does the current political economy of tobacco regulation matter for the design of policies to discourage tobacco use?

\section{DRAMATIS PERSONAE: WHO SHAPES TOBACCO CONTROL POLICY, AND HOW?}

In answering these questions, one must consider how diverse constituencies interact to produce tobacco policy. The ideology, policy preferences, knowledge and material interests of these different constituencies filter through a political process to influence the legislation and enactment of public policy. For more than four decades, the Downsian model of democratic interest group politics has provided the foundation to analyze this process [52-54]. 
This classic model of distributive politics suggests that public regulators face powerful constraints in regulating a wealthy, concentrated, and therefore organized, industry. The largest economic costs of tobacco regulation are borne by the tobacco industry itself. Thus, the industry faces the strongest incentive, and possesses ample resources, to influence the political and economic environment to advance its own interests.

Although the tobacco industry is critical to the political economy of tobacco regulation, other constituencies also play important roles. Significant costs (and benefits) are borne by current smokers, and by non-smokers potentially subjected to environmental exposure. Significant, although imprecisely measured burdens are also imposed on firms that sell tobacco products. Tobacco regulation might also adversely affect other establishments such as restaurants and bars whose customers have high rates of tobacco use. The media, which sells advertising space to tobacco manufacturers and which sells news and entertainment products to end consumers, is also a key stakeholder in the tobacco debate.

The real and perceived interests of these constituencies, their capacity for collective action, and their ability to monitor and influence public policy action, all influence which constituencies become politically active in specific tobacco control measures, and how each of these constituencies respond to public policy change.

The most prominent economic account of regulation is capture theory $[4,5,55,56]$. This framework posits public regulators as the agents of regulated industries themselves, providing a coordinating device for price maintenance, and acting to deter entry by potential competitors. Less obvious, interests outside of the tobacco industry such as media outlets and small retailers, not to mention smokers themselves, also constrain the quality and the politically feasibly range of public health interventions.

Perhaps most surprising, recent political successes in tobacco regulation highlight the limits of a purely distributive model of policy formation and implementation. The tobacco control community, acting in concert with public regulators, trial lawyers and other stakeholders, has won remarkable victories that reflect the unique nature of tobacco, and that reflect the latent but real political strength of the public health enterprise itself. Or so we argue.

\section{Smokers}

The largest, but also the most divided constituency includes the men and women whose health and consumer spending are affected directly by tobacco use [22]. Nearly 50 million current smokers seek convenient access to inexpensive products. Smokers may also oppose public policies that either stigmatize smoking or that use tobacco tax revenue to finance unrelated public expenditure [30,57].

Although smokers are the largest group of Americans with a strong stake in tobacco regulation, demographic trends may have weakened the social standing and political power of smokers in American society. Smoking prevalence has sharply declined among high-income Americans and college-graduates since the 1960s. The large socio-economic gradient in smoking prevalence has led some commentators to oppose further excise tax increases on equity grounds $[14,58]$. In response to these distributional concerns, some tobacco control advocates suggest the use of tobacco revenue to provide health care services to current or past smokers, or that channel resources to low-income individuals generally [15].

Tobacco industry strategists have recognized these patterns, and have sought to mobilize alliances with smoking consumers. One public relations official [31] summarized industry strategy succinctly:

[R.J. Reynolds'] real constituents and potential constituents are smokers and those who support smokers' rights; its enemies are the antismoking lobby ...

Reynolds must become a staunch and outspoken advocate for smokers in their demands ... As in a political campaign, we have to become not only the spokesmen for smokers, but also arm them with the arguments and the information and materials that support these arguments.

\section{Non-smokers}

Current non-smokers are a second constituency important to tobacco control. Some non-smokers support tobacco regulations to avoid environmental tobacco exposures. Such exposures have been associated with adverse health outcomes. Environmental tobacco smoke may also be a nuisance independent of its tangible health risks. A major political strategy of tobacco control advocates was to mobilize individual risk-perceptions and discomfort with smoking into collective, political demands for antismoking measures to reduce such exposures [59].

Parents seeking to discourage youth smoking are another large group with an immediate interest in tobacco policy [48,60]. Parents have proved to be a central political constituency in many substance abuse prevention efforts focused on adolescent use [61].

Smokers, non-smokers and parents are large constituencies with enormous potential to influence the political process. Millions of voters are potentially mobilized as a constituency because they smoke (or are non-smokers) or because they are parents. However, these groups are disorganized constituencies with only limited capacity for 
collective action: limited capacity to identify pertinent political and regulatory concerns, limited capacity to negotiate with other interest groups, to monitor public policy, limited capacity to act cohesively as a group in supporting elected politicians [30,53].

These constituencies therefore express preferences on broad or highly polarized policy debates such as tax increases, but must be mobilized by others to participate in more nuanced debate regarding regulatory enforcement or other matters. Models of distributive politics in the spirit of Downs suggest that these rational, but imperfectly informed and imperfectly attentive constituents are highly influenced by broad ideological frames (protecting health, preserving individual autonomy) that are correlated with specific policy choices [52].

\section{Vendors and other establishments}

Less visible, but perhaps more politically potent, are the tens-of-thousands of vendors who sell tobacco products to the smoking public. These vendors range in size from Wal-Mart to CVS Pharmacy, to bowling alleys or a small news-stand with one employee $[47,62]$. These venders are not part of the tobacco industry, but often profit from cigarettes and related sales.

Vendors are also the principal objects of much tobacco control legislation, including a ban on tobacco vending machines and identification requirements to restrict sales to minors. Vendors are also affected by tobacco excise tax increases that generate increased enforcement activity, may increase competition from illegal sources, and that reduce overall tobacco use [48]. Many studies identify retail industries as critical constituencies for electoral campaigns. Voluntary cooperation of retail vendors is also often required for effective implementation of tobacco control measures.

The case studies summarized by Jacobson and Wasserman explore the role of retail merchants and other commercial establishments in the enactment and enforcement of tobacco regulation [48]. In part out of fear of antagonizing smoking or non-smoking consumers, retail merchants were not vocal participants in the tobacco debate, although these stakeholders were generally a constraining force on tobacco regulation. The actual impact of tobacco on entertainment establishments such as restaurants and bars remains disputed. Some commentators suggest that tobacco control measures harm these industries [63], although these analyses have been questioned sharply by public health analysts [15]. A series of papers by Glantz and collaborators explored the proportion of restaurant sales to total retail sales, finding no difference between communities that enacted such ordinances and matched control communities [64-66].
Trade organizations in several states did oppose enactment or enforcement of youth access measures that included punishment of vendors making under-age sales. Merchants in Florida and elsewhere objected that retail 'sting' operations amounted to entrapment. The Illinois Retail Merchant Association echoed the sentiment of many vendors that the burden of sanctions should fall most heavily on consumers who make illegal purchases, not on the establishments that sell tobacco products. In the arena of clean indoor air, restaurant associations also opposed legislative provisions that imposed additional costs, or that limited firms' flexibility in serving smoking and non-smoking customers. In some states, such as New York, retail merchants also lobbied in the formation of pre-emption legislation [67].

Vendors and merchants posed the greatest challenge to tobacco regulation in the difficulties they encountered in assisting authorities to enforce antismoking regulations. Staff in restaurants and bars face little incentive to antagonize smoking customers. Retail merchants frequently hire teens or other staff members who do not enforce age-specific regulations.

\section{Tobacco farmers and employees}

Tobacco farmers and industry employees have an immediate stake in tobacco regulation. Recent estimates indicate that almost 500000 Americans are employed directly in one of the five core functions of the tobacco industry, and that between 650000 and 2000000 other jobs are connected closely to tobacco sales [68,69]. Tobacco farming is highly concentrated, with $82 \%$ of US tobacco farmers resident in North Carolina, Georgia and Tennessee.

Producers in these states are the primary beneficiaries of tobacco price supports. ${ }^{1}$ This system, whose origins trace to the agricultural dislocation of the Great Depression, is designed to stabilize tobacco leaf prices [71,72]. Price supports provide modest (although symbolically awkward) subsidies to tobacco producers, and have been estimated to increase tobacco market prices slightly [30].

In the long term, both tobacco farmers and tobacco industry employees benefit from continued high demand for tobacco products $[73,74]$. When tobacco regulation is a minor issue in national electoral politics, both groups derive strength from their organization and their geographic concentration. However, tobacco production and distribution employ fewer workers than other, larger or more labor-intensive industries. Within the United States, six states are especially reliant on tobacco production. Yet even within these six, only $1.6 \%$ of jobs are

${ }^{1}$ For more detailed analytical discussion, see the analysis of Babcock \& Foster [70]. 
associated with tobacco core sectors [15]. Only one farmdependent county in the United States derives a majority of farming revenue from tobacco products, although many non-farm-dependent counties in the south-east United States report significant tobacco sales ([75] cited in [15]). In part because of changing consumer habits, and in part because of import competition, the extent and dollar-output of tobacco farming has declined since World War II. The number of US tobacco farms declined from 330000 to 124000 between 1964 and 1993 [69]. Despite these patterns, tobacco remains a highly profitable product.

These geographic ties are reflected in regional patterns of state tobacco regulation. Jacobson, Wasserman \& Anderson summarize state tobacco regulation as it existed during the mid-1990s. Arkansas, Tennessee, West Virginia, North Carolina and Georgia displayed the smallest number of tobacco regulation measures.

\section{Media}

Media organizations appear in two different capacities in shaping the social environment important to tobacco use. As suppliers of news products to end consumers, media are sensitive to tobacco regulation as an important story. Conflict between tobacco companies and public health advocates includes many elements conducive to widespread coverage: clear political conflict over specific policies; allegations of specific wrongdoing by particular firms; the imposition, without consent, of important medical risks through second-hand smoke; the addictive character of nicotine and the use of marketing strategies and advertising designed apparently to reach child and adolescent consumers [11,44,49,59]. Given these elements, the media provided an effective arena for tobacco control advocates to frame their arguments to a broader public.

At the same time, media organizations are also responsive to industry economic power. As a supplier of consumer audiences to commercial advertisers, newspapers, magazines, television and movie entertainment companies respond to the economic power of tobacco companies. As documented in this issue, tobacco advertising is linked with several stages of adolescent tobacco use, and is an important focus of public policy intervention. Tobacco manufacturers are major advertisers in all print media. Although direct television advertising of cigarettes has been banned for nearly three decades, firms that manufacture cigarettes are leading producers of other consumer products such as snack food marketed widely through television advertisements.

These two functions combine uneasily as electronic and print media communicate information and social norms to their readers about tobacco use. The frequency and content of these messages is influenced, although not completely determined, by the economic environment facing this industry: smoking prevalence and interest in public health issues among consumers, the availability and simplicity of pertinent news items to generate coverage.

More subtly, economic dependence of electronic and print media on tobacco manufacturers may also influence the content of tobacco-related coverage [40,41]. As Warner related in Selling Smoke, the leading press critic Ben Bagdikian referred to advertising-motivated suppression of smoking information as the "most shameful money-induced' self-censorship of American media [12]. A 1976 Newsweek cover story entitled 'What causes cancer' failed to emphasize the central role of smoking [12]. Women's magazines with tobacco advertisements provided especially limited coverage of smoking-related health risks [76].

In a historical analysis of magazine news coverage, Warner and colleagues show that magazines that did not carry cigarette advertisements were more likely than magazines that did carry tobacco advertising to publishing at least one article on smoking-related risks. Among women's magazines, those that carried cigarette advertisements were half as likely, in any given year, to publish an article exploring tobacco health risks [41].

Other industries also had a stake in tobacco regulation because smoking is, or may be, an important complement to their services. Most notably, entertainment industries such as bars and restaurants have expressed concern that tobacco regulation may reduce the demand for their services by smoking consumers.

\section{Federal, state, and local policy makers}

Policy makers at all levels of government are also important stakeholders. Public finance theory suggests that all three levels of government enjoy important comparative advantages; yet each of the three has characteristic organizational disadvantages that may hinder its effectiveness.

Federal regulators have primary responsibilities for a variety of regulations designed to constrain youth tobacco use. Although the Food and Drug Administration (FDA) issues extensive regulations, it has limited organizational capacity to directly enforce these regulations. Most notably, the FDA has fewer than 1000 investigators throughout the country [62]. As a result, the FDA contracts important responsibilities to state agencies, many of which have weak organizational commitments to tobacco control.

One policy domain that tested administrative capacities of federal, state and local governments was clean indoor air regulation. During the 1990s, many agencies of 
the federal government enacted clean indoor air regulations covering their own employees and facilities. The Federal Aviation Administration has eliminated smoking on domestic flights. Moreover, the Occupational Safety and Health Administration (OSHA) has considered regulations that would greatly restrict smoking in private worksites. Despite these federal initiatives, states and localities bear primary responsibility to enact, implement, and enforce clean air regulations. Every state but Alabama currently restricts smoking in public places [77].

Although almost every state enacts some form of clean indoor air regulations, such regulations are largely self-enforced by employers and others subject to these regulations. Some states have delegated enforcement to local health departments; yet without accompanying resources and legislative mandates, many localities report minimal enforcement [62].

Ironically, existing studies suggest widespread implementation of clean indoor air regulations despite the practical lack of enforcement resources. Private sector policies, either in compliance with state and federal regulation or voluntary efforts beyond the minimum requirements of such legislation, have moved even more rapidly to address work-place smoking. By 1992, 87\% of private companies with more than 50 employees established smoking policies. Fifty-nine percent banned worksite smoking [46]. Nationally representative 1993 data indicate that $82 \%$ of indoor workers faced some restriction on work-place smoking, and 47\% worked in 100\% smoke-free environments [78].

Policy accomplishments in clean indoor air regulation have not been replicated in the area of youth access, which required more vigorous enforcement, and which often involved 'sting' operations painful to local vendors [47-49]. Case studies by many investigators indicate widespread non-compliance with youth access measures. In many studies, youths report minimal difficulty in obtaining tobacco products despite age-specific laws [47-49].

\section{Excise taxes}

Another important issue concerns the imposition of tobacco excise taxes within a fiscal federalism. Such taxes are especially important in light of evidence that tobacco taxation is a key measure to reduce adolescent use [49].

Because states compete for tobacco revenue, theories of tax competition indicate that a decentralized taxation system is likely to result in lower taxes than would be implemented by federal policy makers acting from the same preferences [79]. Compared with state taxes, federal taxes are less easily evaded, and are therefore more likely to bring the health benefits associated with reduced consumption.
Many policy makers and commentators express special concern that stringent tobacco taxation and regulation will encourage the growth of a black market. Evidence of significant tobacco and alcohol smuggling into Canada-some by subsidiaries of US firms - lends empirical support to the importance of black markets as a policy concern [80-83]. Large gaps in tobacco excise taxes between neighboring states has also spawned significant cross-state traffic [83-85].

At the state level, tobacco industry spokesmen and local vendors have emphasized these possibilities in opposing local tax increases. A 1991 Price Waterhouse study, commissioned by the Tobacco Institute, assessed the effects of tax rises on smuggling. This study concluded the possibilities for cross-border smuggling had increased, and that tax differentials between neighboring states was important to the growth of smuggling activity. Tobacco industry documents such as The Tax Burden on Tobacco highlight this concern.

Some of these concerns are addressed within the economic literature on corruption and black markets for illicit drugs. This literature suggests that black markets can arise or grow in response to stringent regulation. This is a matter of policy concern, especially if tobacco black markets recruit adolescents to an organized criminal economy that brings other behavioral and health risks. Incentives for smuggling and black-market activity are inherent to many forms of regulation - the relevant policy question is to balance these costs with other competing concerns.

Existing literature also suggests that the design of tobacco regulation can have a large impact on the size of the resulting black market and its accompanying social costs. Given ease of interstate travel, municipal and statelevel experiments with tobacco excise taxes are especially vulnerable to smuggling. Changes in national policy such as a federal excise tax create fewer opportunities for criminal intervention.

Moreover, the probable social costs of a tobacco black market are likely to be much smaller than those associated with marijuana or illicit drugs. Given the ease that individuals could divert legal tobacco products into illegal uses, the profit margins available to tax-evading cigarette smugglers are likely to be smaller than those available for cocaine and other intoxicants [86]. Because adolescent smokers are a small extension to a large legal market, youth-specific access restrictions are especially unlikely to spawn a large and highly organized black market.

\section{Federalism, pre-emption, and tobacco regulation}

The debate over excise taxes also highlights more general features of tobacco control. The tobacco industry appears to wield its strongest influence at the state level, and is weaker at the local and (perhaps) federal level [60]. 
Measures such as state pre-emption laws have limited local initiatives for tobacco control [48,77,87]. During the 1990s, many states enacted ordinances to discourage youth smoking and to modestly expand laws which restrict smoking. At the same time, however, states continued to enact pre-emptive legislation and have, in some cases, enacted antidiscrimination statutes to limit smoking legislation.

Pre-emption laws prevent local authorities from enacting restrictions that are more stringent than, or at variance with, the state laws. Between 1982 and 1998, 31 states enacted laws pre-empting local clean indoor air policies, with only Maine repealing successfully a preemptive state smoking law $[45,46,77]$. Supporters of preemption have bargained successfully to attach these measures to antitobacco bills. In addition to the tobacco industry, retailers and vendors have also supported preemption legislation [87]. Pre-emption can result in less stringent tobacco regulation by over-riding local regulations. Preemption can also reduce local public debate about the dangers of tobacco by confining the locus of legislative action to state government.

In addition to pre-emption legislation, tobacco producers, vendors, and consumers have supported state smokers' rights legislation. Documents released in Mangini versus R.J. Reynolds Tobacco Company document industry approaches in this effort [57]. Such legislation was important to the industry to build political ties to current smokers, and also to maintain smoking demand by minimizing the inconvenience and social stigma associated with tobacco use [31].

Smokers' rights laws constrain implementation of work-site no-smoking policies and set clear boundaries around measures [88]. For example, smokers' rights laws would bar hiring discrimination against current smokers. Between 1989 and 1995, 30 states enacted laws prohibiting discrimination against smokers $[77,88]$. Smokers' rights laws attract significant public support and reflect widespread discomfort with explicitly paternalist or punitive tobacco regulatory measures - a sentinent expressed most plainly by Jacob Sullum and other libertarian commentators [89].

\section{Litigators}

An interesting and unique aspect of tobacco regulation is the role of private litigators. Because tobacco is associated with widespread and severe harm, plaintiffs and their attorneysfacestrongincentives touncoverindustrymisconduct [90]. Trial lawyers have possessed the legal tools and the organizational capacity to uncover company documents of great importance to subsequent regulatory efforts [90].

Individuals who have been harmed by tobacco products face a significant collective action problem in seeking damages from the tobacco industry. Individual plaintiffs are often ill, and face uncertain prospects in mounting costly and complex lawsuits against a well-prepared and resourceful defendant that faces strong incentives to resist every such claim. Trial attorneys bring pertinent expertise and incentives to organize these plaintiffs, and to address predictable obstacles to collective action in large product-liability cases against resourceful and wellfinanced firms.

In addition to a common interest in gathering evidence documenting tobacco hazards, tobacco control advocates and trial lawyers faced common incentives to emphasize the specific wrongdoing of the tobacco industry itself. By framing the issue in such polarized terms, litigation reinforced other forms of antitobacco advocacy that together proved politically damaging to the industry [59].

Litigation by government provides similar opportunities for state and local governments. Such litigation also allows policy makers to draw upon the growing political illegitimacy of the tobacco industry in pursuit of either revenue or public health goals.

\section{Elected politicians}

Elected politicians serve several functions in tobacco control. Most overtly, legislators initiate, support or oppose tobacco control legislation. Presidents, governors and mayors support, oppose or veto pertinent legislation. Equally importantly, elected politicians allocate resources, including their own time and attention, to monitor and to implement tobacco control policies. Committee chair-persons allow some items to become prominent on the legislative agenda, while allowing other matters only a cursory hearing. Elected politicians and other high public officials exercise great discretion in the implementation of tobacco regulation. Much of this discretion is exercised out of public view, in matters that may be monitored by specialized constituencies, but that are not monitored by citizens who lack a strong immediate interest in tobacco policy.

Understanding the motivations behind politicians' voting decisions and legislative behavior is a fundamental question of political science [91]. Ideology, the public visibility of the issue and the perceived interests of constituents all play critical roles. Flynn and collaborators provide a detailed analysis of state legislator's intentions to vote for cigarette excise tax increases which examines the importance of pertinent factors at the state level [92]. Legislators who represent tobacco-dependent areas, smokers, males, Republicans and those with sympathetic ideological views were most likely to support the industry. 
One controversial issue concerns the role of tobacco industry contributions. The tobacco industry provides significant resources to both American political parties. At the federal level contributions are focused on the Republican Party, but many Democrats also receive substantial support $[33,93,94]$. It is unclear what, if anything, the industry receives in return.

In crudest form, a legislator might solicit or willingly receive a specific contribution to change a specific pending vote. Less overtly but perhaps more common, an industry might regularly support friendly legislators, under the explicit understanding that such contributions will continue given the legislator's continued support for industry positions. Perhaps most common, an industry can support friendly legislators whose votes are not in doubt, but whose continued success may be enhanced with industry resources [95].

In the case of tobacco, some commentators find evidence that tobacco industry support influenced legislative behavior directly. In a multivariate analysis that controlled for many potential confounders, Glantz \& Begay (1994) found that California legislators who received tobacco industry contributions were more likely to support the industry in their votes on subsequent legislation [96]. Subsequent research by Monardi \& Glantz reported similar findings. [97] Causal inferences from such data are controversial. Critics of such studies respond that the correlation between contributions and voting behavior can be explained by other factors.

\section{Tobacco control advocates}

Less familiar, but perhaps equally important, is the fact that antitobacco coalitions are themselves political actors, who are influenced by internal and external incentives that influence their effectiveness [53,62]. Because citizens monitor controversial new legislation more closely than policy implementation, advocacy groups are rewarded disproportionately based upon their visible role to 'rally around' novel policies. In such an environment, tobacco control advocates face little incentive, and have also developed limited organizational capacity, to monitor regulatory activities patiently long after the key legislation is enacted [98].

Jacobson \& Wasserman (1999) report that none of the antitobacco coalitions they studied had a defined policy for implementation and enforcement. Coalition members were not involved in implementation activities. Case studies of tobacco coalitions also indicate that antitobacco coalitions have not approached retail merchants and other stakeholders who are critical for the success of public regulation [48].

We discuss the current operation of tobacco control coalitions below in more detail, in our 'lessons for policy.

\section{LESSONS FOR POLICY}

We find seven lessons from this story for the design and implementation of public policy.

1 There is no over-arching political economy to tobacco regulation. Each proposed regulation occurs in its own political, economic and institutional context. This context sometimes favors the tobacco industry, and it sometimes favors proponents of tobacco control. Effective action for tobacco control makes best use of favorable opportunities, and alters the policy context when this context is unfavorable to public health measures.

2 Political and economic incentives matter in bargaining over social resources, but so do political values, information, and ideology. The legitimacy of the public health enterprise and widespread public acceptance of the importance of tobacco control are the greatest political assets available for tobacco control advocates. When tobacco advocates visibly link specific policy measures with this broader message, they often overcome the tobacco industry's apparent advantages as a concentrated and wealthy interest group. Tobacco control advocates have found the most success in visible and polarized settings such as tobacco excise tax increases or the passage of other new legislation.

This broad public support for tobacco control appears less potent within the micropolitics of regulatory policy and in other relatively stable policy arenas that operate out of public view. In these settings, the industry's financial and organizational capacities, its ability to bargain patiently with regulators, vendors and others proves most telling.

3 Policy implementation is a distinct political process, one that involves diverse stakeholders who influence the resulting consequences of public policy. Legislative mandates for clean indoor air or against youth tobacco sales are powerful symbolic statements. Absent effective implementation, however, such measures will not accomplish their stated goals.

Elected politicians who have strong incentives to advocate new policies face weaker incentives, and have more limited capacity, to monitor and to improve policy implementation. Citizens evaluate elected politicians based upon the passage of visible new legislation. Citizens are less able to monitor detailed implementation decisions that involve many actors.

Anti-tobacco coalitions are also political actors who face similar perverse incentives that encourage intense efforts to 'rally around' new policies, but that also encourage inattention to important matters of policy implementation once legislation is enacted [98]. Because of such mismatched incentives, tobacco 
advocacy groups overlook important opportunities to inform the public and legislative allies about the quality of public health policy.

4 Tobacco control highlights the importance of social norms in effective regulation. Such norms proved especially important to clean indoor air regulations. Such regulations are minimally enforced by government organizations that have limited capacity for vigilant enforcement. Widespread compliance with such regulation in the absence of strict enforcement proved critical to the long-term impact of clean indoor air regulations. Rabin \& Sugarman express some skepticism about public regulation, arguing that changed civic norms rather than regulation would reduce work-place environmental tobacco smoke. Clean indoor air regulations, although minimally enforced, changed these civil norms by providing a symbolic public statement entitling non-smokers to a smokefree environment. This change had a large impact in work-places and in other settings. Less tangibly, such norms helped to delegitimize the otherwise powerful opposition of smokers to tobacco regulation [48,60]. Anti-tobacco norms have proved less potent in other policy domains. Youth tobacco regulation must deter or identify vendors who sell tobacco products to adolescent consumers. Even if most vendors comply with age-specific restrictions, a less compliant minority can effectively and profitably undermine public policy. In recognition of this problem, the Synar Amendment and other legislation sought to ensure vigorous enforcement. Yet in conditioning substance abuse treatment block grant monies on measures to reduce adolescent sales, the Synar Amendment places the onus of tobacco enforcement onto state agencies with fragmented authority, agencies that often lacked core commitment to tobacco control [62].

More generally, policy makers have not addressed family tobacco exposures-perhaps the most important environmental exposure [99]. Despite widespread condemnation of the tobacco industry, public health advocates have been less successful in promoting a $t$ obacco-free ethic among tobacco farmers, retailers and others who profit from tobacco sales [90,100-102].

5 Excise taxes are most effective when implemented at the federal level. Because states compete for tobacco revenue, and because cross-border smuggling is readily accomplished, decentralized taxation is likely to result in lower taxes than would be implemented by federal policy makers acting from the same preferences. Compared with state taxes, federal taxes are less easily evaded, and are therefore more likely to bring significant health benefits.

6 Tobacco control policies must be structured to create ongoing constituencies for their improvement and effective implementation [103]. In the case of tobacco excise taxes, this suggests that earmarking resulting revenue will be important to sustain the tax over time. Indeed, internal tobacco industry documents note such possibilities with evident concern, citing the practice of earmarking excise tax increases - typically for some "worth-while" hard-to-directly challenge cause...p police pensions, harbor clean-ups, Little League Baseball, and indigent health care' [57].

In similar fashion, an R.J.R. Reynolds strategic public relations plan notes that the need for tax revenue itself is an important political benefit to additional tobacco taxation [31]:

The need to maximize tax revenues, the antismoking lobby's determination to create a smokeless society, and the perception that additional taxes on cigarettes incur little or no political liability, are powerful forces ...

Excise tax revenue can create difficult political tradeoffs for public health advocates who wish to use tobacco excise tax and settlement revenue to improve population health. Although harbor clean-ups, police pensions, general tax relief and even Little League are worthy policies, these measures have little demonstrable public health benefit. Many tobacco control advocates also oppose the use of excise taxes for activities such as indigent health care, which are integral to the public health enterprise but which have little relationship to tobacco control. Because, however, such earmarked activities create powerful constituencies in favor of continued tobacco tax revenues, such policies may contribute to the sustainability of effective public health measures.

7 The incentives and possibilities of tobacco litigation proved important to tobacco control. In a political environment potentially dominated by a wealthy and influential industry, tobacco litigation is especially well-suited to the entrepreneurial model defined by James Q. Wilson, in which a creative advocate can reframe otherwise narrow policy concerns into a 'moralistic crusade' that engages broader public concerns. Similar controversial damage suits against handgun manufacturers are now proceeding, pressed by state and local governments. The long-run impact of such entrepreneurship remains unknown.

Litigation — and the unprecedented Master Settlement Agreement-highlight the fundamental challenge for the future of tobacco regulation. Twenty years ago, unsentimental analysis of the political economy of smoking suggested dim possibilities for the public regulation of smoking. As Harvey Sapolsky (1980) concluded succinctly [30]:

The opportunity to affect significantly the consumption of cigarettes in the United States through 
government action appears quite limited. Fifty million Americans smoke cigarettes. The United States is a leading producer of tobacco leaf and utilizes a price support system which is designed to protect tobacco growers. The industry is profitable and politically well connected. Several states are important producers of tobacco while others benefit from the excise tax imposed on cigarettes. The opposition to smoking is relatively weak and divided.

'Nevertheless', Sapolsky added with considerable prescience, 'the tobacco industry worries about the future market for cigarettes'. During the 1980s and 1990s, all the above factors continued to be strong political assets for the tobacco industry, yet the industry's worries proved, from its own perspective, to be all too accurate.

Many developments contributed to declining smoking prevalence and to the declining political fortunes of the tobacco industry. Declining smoking prevalence among affluent and educated Americans may have weakened the influence of smokers as an organized constituency. Increased scientific knowledge about both smoking hazards and the addictive nature of nicotine may have altered public perceptions of the costs and benefits of tobacco regulation. Changing attitudes about health more generally may have increased the public's willingness to support tobacco control measures.

Without discounting these factors, one of the most important factors was the emergence of tobacco control as a powerful social movement to mobilize constituencies and to promote policy change. As described by Connie Nathanson in greatest depth [59], tobacco control became a successful social movement by accomplishing three tasks: (1) articulating a credible threat to the public's health; (2) being able to mobilize a diverse organizational constituency; and (3) grasping political opportunities converging with a vulnerable opponent. Jacobson \& Wasserman (2001) suggest an additional criterion: the ability to articulate the salience of public health strategies to legislators and to the broader public.

\section{TOBACCO CONTROL IN THE WAKE OF THE MASTER SETTLEMENT AGREEMENT}

At the time, the enactment of the Master Settlement Agreement (MSA) appeared to be a triumph of the tobacco control cause [41]. For the first time, the tobacco industry was forced to pay a large sum of money to redress the harms caused by its products, and forced to fund a major antismoking media campaign. For the second time, the industry was forced to agree to serious restrictions on its marketing and advertising, especially toward youth. The industry was also forced to disband the Tobacco Institute, its research and lobbying organization.

After the failure of the proposed McCain legislation in 1998, the MSA also preserved important regulatory gains that Congress was unlikely to legislate on its own. The agreement allows other tobacco control activity, such as litigation and the enactment of state and local antismoking laws, to continue. The MSA has also contributed to rising cigarette prices, which are likely to discourage youth tobacco initiation. Overall smoking rates have resumed their downward trend after rising sharply (especially for youth) during the early 1990s.

However, this very success poses difficult challenges to the tobacco control cause. If the MSA imposes unprecedented terms on the tobacco industry, the settlement also places tobacco control advocates in the unusual position of arguing about money rather than arguing about ideas and political or policy goals. How should settlement dollars be spent? For tobacco-specific treatment and research? For youth-targeted prevention efforts? For more general substance abuse and public health interventions? For college scholarships or tax relief? For the tobacco control movement to remain politically effective, its diverse members must successfully negotiate such matters while remaining united to support specific policy choices to reduce tobacco use.

It is also arguable that the industry gained certain advantages from the details of the MSA. Like all complex arrangements that unfold over a long period, MSA is neither unambiguous nor self-enforcing. State legislatures must make policy choices in how to spend the settlement income. As suggested in a recent report from the National Council of State Legislatures, state officials have allocated few settlement dollars for tobacco control. Across states in fiscal years 2000 and 2001, 43\% of the funds have been allocated to general health care, and only $9 \%$ to tobacco-related measures [93].

Another advantage to the industry is that the settlement removed pressure on Congress to regulate tobacco, leaving primary tobacco control responsibility with states and localities. Absent the industry's explicit agreement, the Bush Administration appears less aggressive than the Clinton administration in pushing for congressional action, such as increased excise taxes or increased FDA regulatory authority [94]. Such policies matched the skepticism expressed by then-candidate George W. Bush about continued federal litigation to recover tobacco-related medical expenses in Medicare or other federal programs.

MSA poses a second challenge to the tobacco control movement, because the agreement requires careful monitoring, and enforcement. Unexpected contingencies will arise that require careful interpretation. State and federal 
government will enact laws and implement regulations to carry out settlement provisions. The tobacco industry or others (including tobacco advocates themselves) may violate the agreement. Advocates must develop the sustained organizational capacity to successfully address such concerns. For example, the industry challenged and delayed the American Legacy Foundation's antismoking campaign, alleging that the ads vilified the industry in violation of the MSA. Despite the agreement, the industry continued to advertise in magazines with a youth readership.

Perhaps the greatest challenge to the tobacco control movement is less tangible, and is ironically the fruit of its own success. The tobacco control movement is successful because it is a connected, but also critical participant in policy debate. Tobacco control has been successful by changing public policy, but also by altering shaping public attitudes and by changing public discourse regarding tobacco use.

Looking at the entire settlement negotiating history, and not just at the final settlement itself, there is some evidence that the antitobacco coalition is experiencing new strains. In contrast to a relatively unified industry, tobacco control advocates display conflicting agendas and incentives in the political arena.

First, the level of rancor and fragmentation among tobacco control advocates may have undermined their negotiating strategic advantages. From the beginning, advocates failed to achieve consensus on what compromises were acceptable, and advocates were unable to speak with one voice. Advocates could not agree whether or not to grant the industry's demand for immunity from future litigation in return for stringent tobacco control measures. In addition, many advocates insisted on pressing their presumed political advantages during the negotiations over the McCain legislation to the point where the legislation became unsustainable. ${ }^{2}$ This set the stage for the subsequent settlement agreement, which was far less sweeping than the original McCain bill. In short, internal interest group conflict contributed to a negotiated settlement that left many advocates feeling that better terms had eluded them.

Secondly, some advocates wanted nothing short of the industry's capitulation and unconditional surrender. They argued strongly in favor of not conceded anything because they anticipated that successful litigation would achieve their policy objectives, and would result in the industry's bankruptcy [90]. If one believes that litigation is likely to achieve better outcomes than a negotiated political settlement, then the unwillingness to compro-

${ }^{2}$ This is not to blame tobacco control advocates for the demise of the McCain legislation. It is merely to suggest that the inability to obtain consensus led to decisions ultimately contrary to the advocates' policy goals. mise is appropriate. If, on the other hand, one is skeptical of a litigation solution, the more appropriate response is to negotiate the best possible political deal while trying to improve one's political position for future negotiations. For many reasons, it seems unrealistic to expect that tobacco products will not be available in the United States because of large litigation verdicts, calling into question the strategy of relying on litigation to achieve public health objectives.

Thirdly, as the NCSL Report on tobacco settlement expenditures suggests, advocates have not organized effectively at the state level to influence how the funds are allocated. Despite the clear public health implications of how the settlement money is spent, the public health voice seems lacking at the state policymaking level [104].

Playing a political role, with its attendant high profile and national exposure, is exciting. However, in this instance it seems to have been thought of as the end of the process rather than as the prelude to other tactical and strategic battles, such as implementing the settlement. Translating success at the negotiating table into effective policy implementation at the state level seemed to be ignored. No settlement, or even the McCain bill, is likely to end the debate over how to reduce the use of tobacco products. More probably, it will just stimulate other debates about the allocation of tobacco control resources, how to implement and enforce the legislation or settlement, and how to respond to the inevitable tobacco industry rejoinder. Even a string of litigation victories, let alone a single settlement agreement, is not likely to alter the reality that the industry is powerful, creative, and resourceful.

No matter how effective the political negotiations and strategies, the need to strengthen state and local tobacco control coalitions remains. In pursuing the opportunities made possible through litigation and the implementation of detailed policies, tobacco control advocates will aid the operation of many valuable public health measures. Yet in pursuing such activities out of public view, the tobacco control movement runs the risk that it will diminish its less formal, critical role outside the realm of explicit policy. In transforming itself from a social movement into a powerful constituency, the tobacco control movement runs the risk that it will dissipate its animating force. If this happens, the tobacco control movement will undermine its own unique character that proved critical in confronting a politically and economically entrenched threat to public health.

\section{REFERENCES}

1. Jacobson, P., Lantz, P., Warner, K., Wasserman, J., Pollack, H. \& Ahlstrom, A. (2001) Combating Teen 
Smoking: Research and Policy Strategies. Ann Arbor, MI: University of. Michigan Press.

2. Ordeshook, P. (1990) The emerging discipline of political economy. In: Alt, J. E. Shepsle, K. A., eds. Perspectives on Positive Political Economy, pp. 9-30. Cambridge, UK: Cambridge University Press.

3. Elster, J. (1985) Making Sense of Marx. New York: Cambridge University Press.

4. Wilson, J. Q. (1980) Politics of Regulation. New York: Basic Books.

5. Wilson, J. Q. (1989) Bureaucracy: What Government Agencies do and Why They do It. New York: Basic Books.

6. Green, D. P. \& Shapiro, I. (1994) Pathologies of Rational Choice Theory: a Critique of Applications in Political Science. New Haven, CT: Yale University Press.

7. Jha, P. (1999) Curbing the Epidemic: Governments and the Economics of Tobacco Control. Washington, DC: World Bank.

8. Elster, J. (1983) Sour Grapes: Studies in the Subversion of Rationality. New York: Cambridge University Press.

9. Sen, A. (1992) Inequality Reexamined. Cambridge, MA: Russell Sage Foundation, Harvard University Press.

10. Williams, B. A. O. (1985) Ethics and the Limits of Philosophy. Cambridge, MA: Harvard University Press

11. Kluger, R. (1996) Ashes to Ashes: America's Hundred-Year Cigarette War, the Public Health, and the Unabashed Triumph of Philip Morris. New York: Alfred A. Knopf.

12. Warner, K. E. (1986) Selling Smoke. Washington, DC: American Public Health Association.

13. Lynch, J. W., Kaplan, G. A. \& Salonen, J. T. (1997) Why do poor people behave poorly? Variation in adult health behaviours and psychosocial characteristics by stages of the socioeconomic lifecourse. Social Science and Medicine, $44,809-819$.

14. Borren, P. \& Sutton, M. (1992) Are increases in cigarette taxation regressive? Health Economics, 1, 245-253.

15. Warner, K. E. (2000) The economics of tobacco: myths and realities. Tobacco Control, 9, 78-89.

16. Pollack, H., Lantz, P. M. \& Frohna, J. G. (2000) Maternal smoking and adverse birth outcomes among singletons and twins. American Journal of Public Health, 90, 395-400.

17. Marmot, M. \& Wilkinson, R. (2000) Social Determinants of Health. New York: Oxford University Press.

18. Viscusi, W. K. (1992) Smoking: Making the Risky Decision. New York: Oxford University Press.

19. Frohna, J. G., Lantz, P. M. \& Pollack, H. (1999) Maternal substance abuse and infant health: policy options across the life course. Milbank Quarterly, 77, 531-570.

20. Lasser, K., Boyd, J. W., Woolhandler, S., Himmelstein, D. U., McCormick, D. \& Bor, D. H. (2000) Smoking and mental illness: a population-based prevalence study. Journal of the American Medical Association, 284, 2606-2610.

21. Jayakody, R., Danziger, S. \& Pollack, H. (2000) Welfare reform, substance use and mental health. Journal of Health Policy, Politics, and Law, 25, 623-651.

22. Schelling, T. C. (1984) Choice and Consequence. Cambridge, MA: Harvard University Press.

23. US Department of Health and Human Services (USDHHS) (1990) The Surgeon General's 1990 report on the health benefits of smoking cessation: executive summary. Morbidity and Mortality Weekly Report, 39 (RR-12), i-xv, 112.

24. Joad, J. P. (2000) Smoking and pediatric respiratory health. Clinics in Chest Medicine, 21, 37-46, vii-viii.
25. Pollack, H. A. (2001) Sudden infant death syndrome, maternal smoking during pregnancy, and the costeffectiveness of smoking cessation intervention. American Journal of Public Health, 91, 432-436.

26. Floyd, R. L., Rimer, B. K., Giovino, G. A., Mullen, P. D. \& Sullivan, S. E. (1993) A review of smoking in pregnancy: effects on pregnancy outcomes and cessation efforts. Annual Review of Public Health, 14, 379-411.

27. Barillo, D. J., Brigham, P. A., Kayden, D. A., Heck, R. T. \& McManus, A. T. (2000) The fire-safe cigarette: a burn prevention tool. Journal of Burn Care Rehabilitation, 21, 162-164.

28. Brigham, P. A. \& McGuire, A. (1995) Progress towards a fire-safe cigarette. Journal of Public Health Policy, 16, 433439.

29. Leistikow, B. N., Martin, D. C. \& Milan, C. E. (2000) Fire injuries, disasters, and costs from cigarettes and cigarette lights: a global overview. Preventive Medicine, 31, 91-99.

30. Sapolsky, H. M. (1980) The political obstacles to the control of cigarette smoking in the United States. Journal of Health Policy, Politics, and Law, 5, 277-290.

31. R. J. Reynolds Tobacco Company (1990) Proposal for RJR Reynolds' external relations strategy, (RJR Reynolds Company). http://www.library.ucsf.edu/tobacco/ mangini/html/h/069/

32. Abramson, J. (1998) Tobacco industry steps up flow of campaign money. New York Times, Section 1, 8 March.

33. Holman, C. D., Donovan, R. J., Corti, B., Jalleh, G., Frizzell, S. K. \& Carroll, A. M. (1997) Banning tobacco sponsorship: replacing tobacco with health messages and creating health-promoting environments. Tobacco Control, 6 , $115-121$.

34. http://www.tobacco.org/News/aclu11.96.html (1996) Secret documents reveal ACLU tobacco industry ties: NY coalition for a smoke-free city.

35. Mintz, M. (1993) Allies: the ACLU and the Tobacco Industry: Center for Science in the Public Interest, the Coalition on Smoking OR Health. Ralph Nader: Public Citizen, Inc, \& the Trauma Foundation; to Congress. Available at: http:// www.library.ucsf.edu/tobacco/ma/ma.pdf

36. Federal Trade commission (FTC) (1992) Federal Trade Commission Report for 1992-Pursuant to the Federal Cigarette Labeling and Advertising Act. Washington, DC: Federal Trade Commission.

37. Morris, K. (1998) Report points to Formula 1 role in teen smoking. Lancet, 352, 205.

38. Connolly, G. N., Oleans, C. T. \& Blum, A. (1992) Snuffing tobacco out of sport. American Journal of Public Health, 82, 351-353.

39. DiFranza, J. R., Richards, J. W., Paulman, P. M., WolfGillespie, N., Fletcher, C., Jaffe, R. D. \& Murray, D. (1991) RJR Nabisco's cartoon camel promotes camel cigarettes to children. Journal of the American Medical Association, 266, 3149-3153.

40. Warner, K. E. \& Goldenhar, L. M. (1989) The cigarette advertising broadcast ban and magazine coverage of smoking and health. Journal of Public Health Policy, 10, 32 42.

41. Warner, K. E., Goldenhar, L. M. \& McLaughlin, C. (1992) Cigarette advertising and magazine coverage of the hazards of smoking. A statistical analysis. New England Journal of Medicine, 326, 305-309.

42. Burrough, B. \& Helyar, J. (1990) Barbarians at the Gate: the Fall of RJR Nabisco. New York: Harper \& Row. 
43. Redhead, C. (1999) RL30058: Tobacco Master Settlement Agreement (1998): Overview, Implementation by States, and Congressional Issues. Washington, DC: Congressional Research Service.

44. Waxman, H. (1991) Tobacco marketing. Profiteering from children. Journal of the American Medical Association, 266, 3185-3186.

45. Centers for Disease Control (CDC) (2000) State Tobacco Tracking and Evaluation. Atlanta, GA: Centers for Disease Control and Prevention.

46. Fishman, J. A., Allison, H., Knowles, S. B., Wollery, T. A., Marx, W. T., Shelton, D. M., Husten, C. G. \& Eriksen, M. P. (1999) State laws on tobacco control-United States, 1998. CDC Surveillance Summaries. Morbidity and Mortality Weekly Report, 48, 21-62.

47. Jacobson, P. D., Wasserman, J. \& Raube, K. (1993) The politics of antismoking legislation: lessons from six states. Journal of Health Politics, Policy, and Law, 18, $787-$ 819.

48. Jacobson, P. D. \& Wasserman, J. (1997) Tobacco Control Laws: Implementation and Enforcement. Santa Monica, CA: RAND.

49. Lantz, P. M., Jacobson, P. D., Warner, K. E., Wasserman, J., Pollack, H. A., Berson, J. \& Ahlstrom, A. (2000) Investing in youth tobacco control: a review of smoking prevention and control strategies. Tobacco Control, 9, 47-63.

50. Glantz, S. A. (1996) Preventing tobacco use-the youth access trap. American Journal of Public Health, 86, 156158.

51. Bigcharts (2000) Bigcharts.com

52. Downs, A. (1957) An Economic Theory of Democracy. New York: Harper.

53. Moe, T. M. (1980) The Organization of Interests: Incentives and the Internal Dynamics of Political Interest Groups. Chicago, IL: University of Chicago Press.

54. Olson, M. (1971) The Logic of Collective Action. Cambridge: Harvard University Press.

55. Stigler, G. J. (1971) The theory of economic regulation. Bell Journal of Economics and Management Science, 2, 2-21.

56. Stigler, G. J. (1975) The Citizen and the State: Essays on Regulation. Chicago, IL: University of Chicago Press.

57. RJRTC. (1990) Smokers' rights documents-UCSF documents H002834-H002838. RJ Reynolds Tobacco Company. http://www.library.ucsf.edu/tobacco/mangini/ $\mathrm{html} / \mathrm{h} / 216 /$

58. Samuelson, R. J. (1998) The amazing smoke screen. The anti-tobacco crusade is a reverse Robin Hood arrangement. It robs the poor to pay the rich. Newsweek, 132 (30 November), 47.

59. Nathanson, C. A. (1999) Social movements as catalysts for policy change: the case of smoking and guns. Journal of Health Politics, Policy and Law, 24, 421-488.

60. Jacobson, P. D., Wasserman, J. \& Anderson, J. R. (1997) Historical overview of tobacco legislation and regulation. Journal of Social Issues, 53, 75-95.

61. Massing, M. (1998) The Fix. New York: Simon and Schuster.

62. Jacobson, P. D. \& Wasserman, J. (1999) The implementation and enforcement of tobacco control laws: policy implications for activists and the industry. Journal of Health Politics, Policy and Law, 24, 567-598.

63. Dunham, J. \& Marlow, M. L. (2000) Smoking laws and their differential effects on restaurants, bars, and taverns. Contemporary Economic Policy, 18, 326-333.
64. Glantz, S. A. \& Smith, L. R. (1994) The effect of ordinances requiring smoke-free restaurants on restaurant sales. American Journal of Public Health, 84, 1081-1085.

65. Glantz, S. A. \& Smith, L. R. (1997) The effect of ordinances requiring smoke-free restaurants and bars on revenues: a follow-up. American Journal of Public Health, 87, 1687-1693.

66. Glantz, S. A. \& Charlesworth, A. (1999) Tourism and hotel revenues before and after passage of smoke-free restaurant ordinances. Journal of the American Medical Association, 281, 1911-1918.

67. Jacobson, P. D. \& Wu, L. (2001) Clean indoor air restrictions: progress and promise. In: Rabin, R. Sugarman, S., eds. Regulating Tobacco: Premises and Policy Options, pp. 175-197. New York: Oxford University Press.

68. Gale, F. (1997) Tobacco Dollars and Jobs. Tobacco Situation and Outlook. TBS-239. http://www.tobaccoweek.com/ tw3_currents.asp? area $=4 \&$ article $=17$

69. Chaloupka, F. \& Warner, K. E. (2000) The Economics of smoking. In: Culyer, A. Newhouse, J., eds. Handbook of Health Economics, pp. 1539-1627. Amsterdam, the Netherlands: Elsevier Science.

70. Babcock, B. A.\&Foster, W.E. (1992) Economic rents under supply controls with marketable quota. American Journal of Agricultural Economics, 74, 630-637.

71. Zhang, P. \& Husten, C. (1998) Impact of the tobacco price support program on tobacco control in the United States. Tobacco Control, 7, 176-182.

72. Zhang, P., Husten, C. \& Giovino, G. (2000) Effect of the tobacco price support program on cigarette consumption in the United States: an updated model. American Journal of Public Health, 90, 746-750.

73. Warner, K. E., Fulton, G. A., Nicolas, P. \& Grimes, D. R. (1996) Employment implications of declining tobacco product sales for the regional economies of the United States. Journal of the American Medical Association, 275 , 1241-1246.

74. Warner, K. E. \& Fulton, G. A. (1994) The economic implications of tobacco product sales in a nontobacco state. Journal of the American Medical Association, 271, 771-776.

75. Gale, F. (1998) Economic structure of tobacco-growing regions. Tobacco Situation and Outlook, TBS-241, 40-47.

76. Whelan, E. M., Sheridan, M. J., Meister, K. A. \& Mosher, B. A. (1981) Analysis of coverage of tobacco hazards in women's magazines. Journal of Public Health Policy, 2, 28-35.

77. Jacobson, P.\& Wu, L. (2001) Clean Indoor Air Restrictions: Progress and Promise. In: Rabin, R. L., Sugarman, S. S., eds. Regulating Tobacco, pp. 207-244. New York: Oxford University Press.

78. Farrelly, M. C., Evans, W. N. \& Sfekas, A. E. (1999) The impact of workplace smoking bans: results from a national survey. Tobacco Control, 8, 272-277.

79. Wrede, M. (1999) Tragedy of the fiscal common?: fiscal stock externalities in a leviathan model of federalism. Public Choice, 101, 177-193.

80. Drew, C. (1998) RJR Nabisco unit admits smuggling: cigarette seller evaded taxes, using Mohawk reservation. New York Times, 23 December, p. A1.

81. Fennell, T. (1994) Risky business: tax-weary Canadians help support a boom in smuggled alcohol. Maclean's, 107, 14-16.

82. Galbraith, J. W. \& Kaiserman, M. (1997) Taxation, smuggling and demand for cigarettes in Canada: evidence 
from time-series data. Journal of Health Economics, 16, 287301.

83. Gleckman, H. (1998) Firing up a black market: illegal cigarettes may follow tax hikes. Business Week, 3579, 25 May, 26.

84. Saba, R. P., Beard, T. R. \& Ekelund, R. B. (1995) The demand for cigarette smuggling. Economic Inquiry, 33, 189-202.

85. Thursby, J. G. \& Thursby, M. C. (2000) Interstate cigarette bootlegging: extent, revenue losses, and effects of federal intervention. National Tax Journal, 53, 59-77.

86. Kleiman, M. (1992) Against Excess: Drug Policy for Results. New York: Basic Books.

87. Siegel, M., Carol, J., Jordan, J., Hobart, R., Shoenmarklin, S., DuMuelle, F. \& Fisher, P. (1997) Preemption in tobacco control: review of an emerging public health problem. Journal of the American Medical Association, 278, 858-863.

88. Bartelt, J. (1995) State Legislative Actions on Tobacco Issues. Washington, DC: Coalition on Smoking OR Health (CSOH).

89. Sullum, J. (1998) For your own good: the anti-smoking crusade and the tyranny of public health. New York Times, 30 July, pp. E8.

90. Jacobson, P. D. \& Warner, K. E. (1999) Litigation and public health policy making: the case of tobacco control. Journal of Health Politics, Policy, and Law, 24, 769-804.

91. Kingdon, J. (1989) Congressmens' Voting Decisions. Ann Arbor, MI: University of Michigan Press.

92. Flynn, B. S., Goldstein, A. O., Solomon, L. J., Bauman, K. E., Gottlieb, N. H., Cohen, J. E., Munger, M. C. \& Dana, G. S. (1998) Predictors of state legislators' intentions to vote for cigarette tax increases. Preventive Medicine, 27, 157-165.

93. Winter, G. (2001) State officials are faulted on anti-tobacco programs. New York Times, January 11.

94. Stolberg, S. (2001) Choice for health secretary is faulted on tobacco issue. New York Times, January 12.
95. Corrado, A. (1997) Campaign Finance Reform: a Sourcebook. Washington, DC: Brookings Institution Press.

96. Glantz, S. A. \& Begay, M. E. (1994) Tobacco industry campaign contributions are affecting tobacco control policymaking in California. Journal of the American Medical Association, 272, 1176-1182.

97. Monardi, F. \& Glantz, S. A. (1998) Are tobacco industry campaign contributions influencing state legislative behavior? American Journal of Public Health, 88, 918-923.

98. McCubbins, M. D. \& Schwartz, T. (1984) Congressional oversight overlooked: police patrols versus fire alarms. American Journal of Political Science, 28, 165-179.

99. Brownson, R. C., Eriksen, M. P., Davis, R. M. \& Warner, K. E. (1997) Environmental tobacco smoke: health effects and policies to reduce exposure. Annual Review of Public Health, 18, 163-185.

100. Mosher, J. F. (1995) The merchants, not the customers: resisting the alcohol and tobacco industries' strategy to blame young people for illegal alcohol and tobacco sales. Journal of Public Health Policy, 16, 412-432.

101. Forster, J. L., Hourigan, M. \& McGovern, P. (1992) Availability of cigarettes to underage youth in three communities. Preventive Medicine, 21, 320-328.

102. Altman, D. G., Linzer, J., Kropp, R., Descheemaeker, N., Feighery, E. \& Fortmann, S. P. (1992) Policy alternatives for reducing tobacco sales to minors: results from a national survey of retail chain and franchise stores. Journal of Public Health Policy, 13, 318-331.

103. Skocpol, T. (1993) Protecting Soldiers and Mothers: the Political Origins of Social Policy in the United States. Cambridge, MA: Belknap Press of Harvard University Press.

104. Jacobson, P. \& Wasserman, J. (2001) Missing in action: the public health voice in policy debates [Editorial]. Journal of Public Health Management Practice, 7, IX-X. 